\title{
PROBING-PROMTING LEARNING BERBANTU BAHAN AJAR DESAIN DIDAKTIS: DAMPAKNYA TERHADAP PEMAHAMAN KONSEP MATEMATIS
}

\author{
Ima Damayanti ${ }^{1}$, Achi Rinaldi ${ }^{2}$, Rizki Wahyu Yunian Putra ${ }^{3}$ \\ UIN Raden Intan Lampung, Jalan Endro Suratmin, Sukarame-Bandar Lampung ${ }^{1,2,3}$ \\ e-mail: imadamayanti445@gmail.com
}

\begin{abstract}
ABSTRAK
Tujuan penelitian ini adalah untuk mengetahui apakah terdapat pengaruh pemahaman konsep matematis berdasarkan model pembelajaran Probing-Promting menggunakan bahan ajar desain didaktis. Pada penelitian ini terdapat dua variable, yaitu variable bebas dan variable terikat. Model pembelajaran Probing-Promting menggunakan bahan ajar desain didaktis sebagai variable bebas dan pemahaman konsep matematis sebagai variable terikat. Metode yang digunakan dalam penelitian ini adalah Quisi Experimental Design. Populasi pada penelitian ini adalah peserta didik kelas VIII SMP Negeri 1 Abung Timur. Berdasarkan hasil perhitungan statistik kemampuan pemahaman konsep matematis menggunakan uji ANOVA, terdapat pengaruh model pembelajaran Probing-Promting menggunakan bahan ajar desain didaktis terhadap kemampuan pemahaman konsep matematis siswa.
\end{abstract}

\section{Kata kunci:}

Probing-Promting; Desain Didaktis; dan Pemahaman Konsep Matematis

\begin{abstract}
The purpose of this study was to determine whether there is an influence of understanding mathematical concepts based on the Probing-Promting learning model using didactic design teaching materials. In this study, there are two variables, namely the independent variable and the dependent variable. The Probing-Promting learning model uses didactic design teaching materials as the independent variable and understanding of mathematical concepts as the dependent variable. The method used in this research is Quisi Experimental Design. The population in this study were students of class VIII SMP Negeri 1 Abung Timur. Based on the results of statistical calculations of the ability to understand mathematical concepts using the ANOVA test, there is an influence of the Probing-Promting learning model using didactic design teaching materials on students' ability to understand mathematical concepts.
\end{abstract}

Keywords:

Probing-Promting; Didactical Design; and Understanding Mathematicals Concept

\section{PENDAHULUAN}

Penididikan menjadi unsur penting dalam membangun sumber daya manusia secara nasional yang memiliki fungsi untuk meningkatkan kualitas hidup masyarakat melalui proses pembelajara (Putri, Mujib, \& Fredi, 2016). Tujuan pembejaran yaitu untuk memperoleh pengetahuan, melatih kemampuan intelektual, dan merangsang keingintahuan peserat didik (Bambang, 2016). Teknologi menjadi media untuk mempermudah pendidik dalam menyampaikan materi pelajaran. Penggunaan media yang tepat dapat membantu peserta didik lebih mudah dalam memahami konsep matematis. Pendidikan membuat manusia berusaha mengembangkan dirinya agar mampu menghadapi setiap perubahan yang terjadi akibat adanya kemajuan teknologi (Putra, \& Anggraini, 2016)

Matematika menjadi salah satu pelajaran yang penting dalam pendidikan karena berhubungan dengan ide dan konsep yang tersusun berdasarkan penalaran matemtais (Sarniah, Chairul, \& Rizki, 2019). Matematika merupakan sarana berpikir untuk mengkaji masalah 


\section{$\pi$ (Phi)}

secara logis, kritis, rasional, dan sistematis, yang dapat melatih peserta didik terbiasa memcahkan masalah yang ada dilingkungan sekitar (Alin, Nasir, \& Komar, 2018).

Selama ini mata pelajaran matematika dianggap peserta didik sebagai mata pelajaran yang sukar dan kurang diminati karena terkesan rumit untuk dipahami, salah satu kesulitannya yaitu memahami konsep matemtaika. Pemahaman konsep menjadi dasar untuk berpikir, belajar, dan kemudian mememcahkan masalah (Sudi, 2016). pemahaman konsep menjadi prasyarat untuk memahami materi berikutnya (Asrul, 2012). Sehingga pemahaman konsep matematis terus menjadi salah satu tujuan utama dari pelajaran matematika (Simon, 2017). Dengan kemampuan tersebut diharapkan peserta didik mampu berpikir kritis, logis, cermat, analitis dan disiplin sehingga mampu diterapkan pada ilmu lain dan menerapkannya di kehidupan sehari-hari.

Berdasarkan hasil wawancara dengan salah satu pendidik pelajaran matematika yang peneliti lakukan pada saat pra penelitian di SMP Negeri 1 Abung Timur diperoleh informasi bahwa rendahnya kemampuan pemahaman konsep matematis dipengaruhi oleh beberapa faktor, pendapat peserta didik yang menganggap matematika sangat sulit dan kurang mengasyikkan hingga membuat peserta didik kurang memperhatikan materi yang disampaikan, selain model yang digunakan adalah model pembelajaran langsung dan kurangnya varisai bahan ajar yang digunakan.

Hal tersebut menunjukkan bahwa kendala yang dialami peserta didik SMP Negeri 1 Abung Timur dalam proses pembelajaran yaitu pemahaman konsep matematis yang dimiliki peserta didik masih tergolong dalam pembelajaran konvensional. Kemudian peneliti memberikan tes kemampuan pemahaman konsep. Tes yang diberikan merupakan pemberian soal uraian yang dikerjakan oleh peserta didik, rangkuman hasil tes dapat dilihat pada tabel berikut:

Tabel 1. Data Hasil Tes Kemampuan Pemahaman Konsep Peserta didik kelas VIII SMP Negeri 1 Abung Timur

\begin{tabular}{cccc}
\hline \multirow{2}{*}{ Kelas } & \multicolumn{2}{c}{ Interval nilai } & Jumlah \\
& Nilai $<75$ & Nilai $\geq 75$ & peserta \\
\hline VIII A & 21 & 1 & 22 \\
\hline VIII B & 20 & 0 & 20 \\
\hline VIIIC & 22 & 0 & 22 \\
\hline Jumlah & 63 & 1 & 64
\end{tabular}

Sumber : Olah data prapenelitian kelas VIII SMP Negeri 1 Abung Timur

Melihat dari permasalahan diatas mengindikasikan bahwa kemampuan pemahaman konsep matematis peserta didik di SMP Negeri 1 Abung Timur pada umumnya masih tergolong rendah. Rendahnya hasil belajar dapat diakibatkan oleh proses pembelajaran yang kurang efektif terutama kurangnya jam pelajaran Maka diperlukannya adanya model pembelajaran inovasi baru (Yanti, Farida, \& Iip, 2019). Model pembelajaran dapat dijadikan pola pilihan, yang berarti pendidik dapat memilih model pembelajaran yang sesuai dan efisien untuk mencapai tujuan pembelajaran (Rusman, 2012).

Model pembelajaran ProbingPromting memiliki arti yaitu, Probing berate penyelidikan atau pemeriksaan bertujuan untuk memperoleh sejumlah informasi yang ada pada diri siswa untuk memahami pengetahuan atau konsep yang baru, sementara Promting berarti menuntun atau mendorong (Susanto, 2018). Model pembelajaran Probing Promting yang akan digunakan dalam proses pembelajaran akan menuntut untuk berfikir kritis dalam memahami materi yang diberikan dan dalam menggunakan model probing promting pendidik dapat melakukan proses tanya jawab yang dilakukukan secara acak, sehingga model 


\section{$\pi$ (Phi)}

pembelajaran ini juga menuntut peserta didik harus berpartisipasi secara aktif.

Aisah, Kusnandi, \& Yulianti berpendapat bahwa desain didaktis merupakan rancangan pembelajaran berupa bahan ajar yang dibuat berdasarkan penelitian learning obstacle pada pembelajaran matematika yang telah muncul (Ria, 2019). Didactical Design Research (DDR) berdasarkan pendapat Suryadi adalah penelitian yang dilaksanakan melalui tiga tahap, antara lain yaitu: (1) Analisis situasi didaktis sebelum pembelajaran yang wujudnya berupa Desain Didaktis Hipotesis termasuk ADP (Antisipasi Didaktis Pedagogis), (2) analisis metapedadidaktik, dan (3) analisis retrosfektif, yakni analisis yang mengaitkan hasil analisis situasi didaktis hipotesis dengan hasil analisis metapedadidaktik (Sulistiawati, Suryadi, \& Fatimah, 2015). Desain didaktis mengenal istilah learning obstacle. Dimana learning obstecle merupakan hambatan belajar yang dialami dengan para siswa didalam proses belajar. Hubungan antara siswa dengan guru disebut pedagogical relation (Hubungan Pedagogis/HP) sedangkan hubungan antara siswa dengan materi disebut dengan didactical relation (Hubungan Didaktis/ HD), yang biasa disajikan dalam segitiga didaktis. Dalam hal ini, pendidik dapat merancang sebuah situasi didaktis dan membuat prediksi tanggapan siswa serta antisipasinya hingga terjadi situasi yang baru.

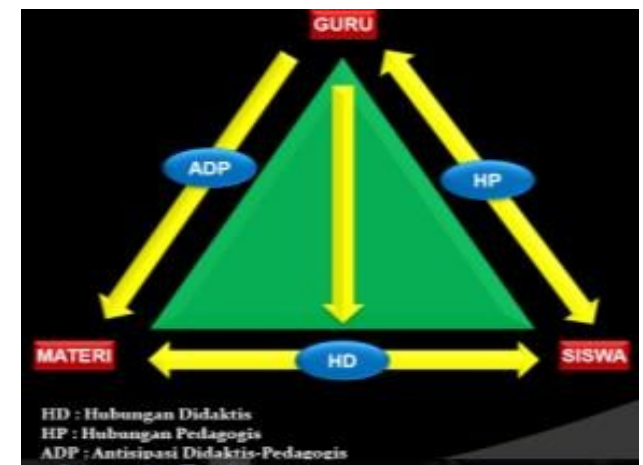

Gambar 1. Segitiga Didaktis Modifikasi
Jurnal Pendidikan Matematika

Volume 5 Nomor 1 Tahun 2021
Pemahaman konsep adalah penanaman, yang bertujuan untuk membuat siswa lebih memahami konsep matematika(Thahir, Pawarni, \& Palupi, 2019). Skemp berpendapat kemampuan pemahaman itu adalah (Anna, 2015):

1) Pemahaman instrumental yaitu siswa dapat menghapalkan rumus-rumus, mampu menerapkan rumus pada saat perhitungan sederhana dan mengerjakan pehitungan secara algoritmik.

2) Pemahaman relasional, yaitu siswa dapat menghubungkan sesuatu dengan hal lainnyadengan tepat serta mengetahui prosesnya.

National Council of Teachers of Mathematics (NCTM) menyatakan pengetahuan dan pemahaman siswa terhadap konsep matematis dapat dilihat dari kemampuan siswa berikut ini:

1) Mengartikan sebuah konsep baik secara tertulis ataupu secara lisan

2) Mengidentifikasi membuat contoh ataupun bukan contoh

3) Mempresentasikan konsep dengan menggunakan model, diagram, ataupun simbol.

4) Dari bentuk presentasi diubah ke dalam bentuk lainnya

5) Mengenal berbagai makna dan interpretasi konsep

6) Mengenal syarat untuk menentukan suatu konsep dan mengidentifikasi sifat-sifat suatu konsep dapat membedakan juga membandingkan konsep

Berdasarkan uraian diatas peneliti berupaya mengatasi permasalahan yang ada dengan mengamati model pembelajaran Probing-Promting menggunakan bahan ajar desain didaktis terhadap kemampuan pemahaman konsep matematis. 


\section{$\pi$ (Phi)}

\section{METODE PENELITIAN}

Penelitian ini menggunakan penelitian kuantitatif dengan metode Quasi Eksperimen Design. Quasi eksperimen berfungsi untuk mengetahui pengaruh perlakuan terhadap karakteristik subjek yang diinginkan oleh peneliti. Pada penelitian ini terdapat dua variable, yaitu variable bebas dan variable terikat. Penelitian ini menerapkan model pembelajaran Probing-Promting menggunakan bahan ajar desain didaktis pada tiga kelompok yang dipilih secara random. Kelompok pertama sebagai kelas eksperimen dengan perlakuan pembelajaran Probing-Promting menggunakan bahan ajar desain didaktis, kemudian kelompok kedua sebagai kelas eksperimen, yaitu peserta didik yang mendapat perlakuan (treatment) model pembelajaran Probing-Promting dan kelompok ketiga sebagai kelas kontrol, yaitu peserta didik yang mendapat perlakuan model pembelajaran konvensional. Ketiga kelas diasumsikan sama dalam segi yang relevan, hanya berbeda pada perlakuan $\mathrm{X}$ yang diberikan.

Tabel 2. Desain penelitian

\begin{tabular}{cccc}
\hline Kelompok & Pre-test & Treatmen & $\begin{array}{c}\text { Post- } \\
\text { Test }\end{array}$ \\
\hline Eksperimen 1 & $\mathrm{Y}_{1}$ & $\mathrm{X}_{1}$ & $\mathrm{Y}_{2}$ \\
\hline Eksperimen 2 & $\mathrm{Y}_{3}$ & $\mathrm{X}_{2}$ & $\mathrm{Y}_{4}$ \\
\hline Kontrol & $\mathrm{Y}_{5}$ & $\mathrm{X}_{3}$ & $\mathrm{Y}_{6}$ \\
\hline
\end{tabular}

Pada penelitian ini terdapat dua variabel, variabel yang memengaruhi yaitu model pembelajaran Probing-Promting menggunakan bahan ajar desain didaktis (Variabel Bebas) dan variabel yang dipengaruhi adalah pemahaman konsep matematis (Variabel Terikat).

Populasi dalam penelitian ini adalah siswa kelas VIII SMP Negeri 1 Abung Timur,. Terdapat beberapa teknik pengumpulan data yang digunakan yaitu wawancara dan tes. Instrumen penelitian yang digunakan ialah tes kemampuan kemampuan pemahaman konsep matematis. Penelitian ini menggunakan uji instrumen penelitian berupa uji validitas, uji reliabilitas, uji tingkat kesukaran dan uji daya pembeda. Teknik uji hipotesis yang akan digunakan dalam penelitian ini adalah ANOVA untuk mengetahui ada atau tidaknya perbedaan nilai antar kelompok yang diberikan perlakuan dan yang tidak diberi perlakuan. Dalam penelitian ini peneliti menggunakan teknik statistik melalui uji anova satu jalan dengan sel tak sama. Uji ini digunakan untuk melihat efek variabel bebas terhadap variabel terikat dengan membandingkan rataan beberapa populasi. Langkahlangkah pengujian ANOVA (Achi, Novalia, \& Syazaki, 2020), yaitu:

a. Rumusan hipotesis statistik:

Ho : $\mu_{1}=\mu_{2}=\mu_{3}$

Ha : paling sedikit ada dua rataan yang tidak sama

b. Tentukan taraf signifikan $(\alpha): 0,05$

c. Komputasi

Untuk memudahkan perhitungan, didefinisikan besaran-besaran (1), (2), dan (3) sebagai berikut:
(1) $=\frac{G^{2}}{N}$
$(2)=\sum_{i, j} X_{i, j}^{2}$
(3) $=\sum_{j} \frac{T_{j}^{2}}{n_{j}}$

Berdasarkan besaran-besaran itu, JKA, JKG, dan JKT diperoleh dari:

- $\mathrm{JKA}=(3)-(1)$

- $J K G=(2)-(3)$

- $\mathrm{JKT}=\mathrm{JKG}+\mathrm{JKA}$

Dengan:

JKA = Jumlah kuadrat baris

$\mathrm{JKG}=$ Jumlah kuadrat galat

$\mathrm{JKT}=$ Jumlah kuadrat total

Derajat untuk masing masing jumlah kuadrat dan derajat kebebasan untuk masing masing diperoleh rataan kuadrat berikut :

$$
R K A=\frac{J K A}{d K A} R K G=\frac{J K G}{d K G}
$$


d. Statistik Uji

Statistik uji untuk analisis variansi ini adalah:

$$
F_{o b s}=\frac{J K A}{J K G}
$$

Yang merupakan nilai dari variabel random yang berdistribusi $\mathrm{F}$ dengan derajat kebebasan $k-1$ dan $N-k$

e. Daerah Kritis

$D K=\left\{F \mid F>F_{a ; k-1 ; N-k}\right\}$

Tabel 3. Rangkuman Analisis Variansi Satu Jalan

\begin{tabular}{|c|c|c|}
\hline Sumber & $\begin{array}{c}\text { Perlakuan }(\mathrm{A}) \\
\text { Galat }(\mathrm{G})\end{array}$ & $\begin{array}{l}\text { Jumlah } \\
(\mathrm{T})\end{array}$ \\
\hline $\begin{array}{l}\text { Jumlah Kuadrat } \\
\text { (JK) }\end{array}$ & $\begin{array}{l}\text { JKA } \\
\text { JKG }\end{array}$ & JKT \\
\hline $\begin{array}{l}\text { Derajat } \\
\text { Kebebasan (dk) }\end{array}$ & $\begin{array}{l}\mathrm{k}-1 \\
\mathrm{~N}-\mathrm{k}\end{array}$ & $\mathrm{N}-1$ \\
\hline $\begin{array}{l}\text { Rataan Kuadrat } \\
\text { (RK) }\end{array}$ & $\begin{array}{l}\text { RKA } \\
\text { RKG }\end{array}$ & - \\
\hline$F_{o b s}$ & $\frac{J K A}{J K G}$ & - \\
\hline$F_{\alpha}$ & $\mathrm{F}^{*}$ & - \\
\hline$\alpha$ & 0,05 & - \\
\hline
\end{tabular}

\section{f. Keputusan Uji}

$\mathrm{H}_{0}$ ditolak jika $\mathrm{F}_{\text {hitung }}$ terletak di daerah kritis atau, tolak $\mathrm{H}_{0}$ jika $\mathrm{F}_{\text {hitung }}>\mathrm{F}_{\text {tabel }}$

\section{HASIL DAN PEMBAHASAN}

Penelitian ini dilaksakan di SMP Negeri 1 Abung Timur pada kelas VIII tahun ajaran 2020/2021. Kelas yang diberikan perlakuan model pembelajaran Probing-Promting menggunakan bahan ajar desain didaktis adalah kelas VIII A, kelas yang diberikan perlakuan model pembelajaran Probing-Promting adalah kelas VIII B, sedangkan kelas yang diberikan perlakuan pembelajaran konvensional adalah kelas VIII C. Jumlah peserta didik pada masing-masing kelas adalah 30 orang. Penelitian ini terfokus pada materi persamaan garis lurus. Pada penelitian ini menggunakan tes awal
(Pretest) untuk mengetahui kemampuan awal peserta didik terhadap kemampuan pemahaman konsep matematis, selanjutnya akan diberikan tes akhir (Postest) untuk mengetahui berapa besarnya pengaruh model pembelajaran Probing-Promting menggunakan bahan ajar desain didaktis. Tes yang diberikan sebanyak 8 soal uraian yang telah dilakukan uji instrumen sebelumnya.

Berdasarkan data nilai hasil pretest kemampuan pemahaman konsep matematis peserta didik, diperoleh nilai tertinggi $\left(X_{\text {maks }}\right)$, nilai terendah $\left(X_{\min }\right)$, median, modus, jangkauan dan simpangan baku $(S)$ pada kelas eksperimen maupun kelas kontrol. Rangkuman hasil data amatan nilai kemampuan representasi matematis dapat dilihat pada tabel berikut :

Tabel 4. Deskripsi Data Hasil Pretest Kemampuan Pemahaman Konsep

\begin{tabular}{cccc}
\hline \multirow{2}{*}{ Nilai } & \multicolumn{3}{c}{ Kelas } \\
\cline { 2 - 4 } & $\begin{array}{c}\text { Eskperimen } \\
\mathbf{1}\end{array}$ & $\begin{array}{c}\text { Eskperimen } \\
\mathbf{2}\end{array}$ & Kontrol \\
\hline$X_{\max }$ & 57 & 57 & 57 \\
\hline$X_{\min }$ & 14 & 18 & 14 \\
\hline $\bar{x}$ & 36,47 & 37,6 & 35,6 \\
\hline$M_{o}$ & 37,5 & 36 & 36 \\
\hline$M_{e}$ & 29 & 36 & 36 \\
\hline $\mathrm{R}$ & 43 & 39 & 43 \\
\hline $\mathrm{S}$ & 10,47 & 9,62 & 10,85 \\
\hline
\end{tabular}

Berdasarkan rangkuman pada tabel 4 peserta didik dari ketiga kelas memperoleh angka nilai tertinggi yang sama yaitu 57. Nilai terendah pada kelas eksperimen 1 adalah 14, kelas eksperimen 2 adalah 18, dan pada kelas kontrol adalah 14. Rataan nilai peserta didik pada kelas eksperimen 1 sebesar 36,47, kelas eksperimen 2 sebesar 37,6, dan kelas kontrol sebesar 35,6. Modus pada kelas eksperimen 1 adalah 37,5 dan pada kelas eksperimen 2 dan kelas kontrol adalah 36. Nilai tengah atau median pada kelas eksperimen 1 adalah 29 dan pada kelas eksperimen 2 dan kelas kontrol adalah 36. Rentang nilai pada kelas eksperimen 1 dan kelas kontrol adalah 43, 


\section{$\pi$ (Phi)}

sedangkan pada kelas eksperimen 2 sebesar 39. Simpangan baku kelas eksperimen 1 sebesar 10,47, kelas eksperimen 2 sebesar 9,62, dan kelas kontrol sebesar 10,85. disimpulkan bahwa pemahaman konsep matematis peserta didik pada kelas eksperimen memiliki kemampuan yang sama jika dilihat pada kelas kontrol dari nilai tertinggi, nilai terendah dan ukuran tendensi sentral.

Selain itu diperoleh pula hasil posttest dari ketiga kelas, dapat dilihat pada rangkuman tabel berikut:

Tabel 5. Deskripsi Data Hasil Postest Kemampuan Pemahaman Konsep

\begin{tabular}{cccc}
\hline \multirow{2}{*}{ Nilai } & \multicolumn{3}{c}{ Kelas } \\
\cline { 2 - 4 } & Eskperimen & Eskperimen & Kontrol \\
& $\mathbf{1}$ & $\mathbf{2}$ & \\
\hline$X_{\max }$ & 100 & 96 & 93 \\
\hline$X_{\min }$ & 61 & 50 & 43 \\
\hline $\bar{x}$ & 84,9 & 76,07 & 67 \\
\hline$M_{o}$ & 93 & 86 & 57 \\
\hline$M_{e}$ & 87,5 & 79 & 68 \\
\hline $\mathrm{R}$ & 39 & 46 & 50 \\
\hline $\mathrm{S}$ & 10,179 & 11,546 & 12,14 \\
\hline
\end{tabular}

Berdasarkan rangkuman pada tabel 4.11 perolehan nilai Postest siswa dengan nilai tertinggi pada kelas eksperimen 1 adalah 100, kelas eksperimen 2 adalah 96, sedangkan dikelas kontrol adalah 93. Nilai terendah pada kelas eksperimen 1 adalah 61, kelas eksperimen 2 adalah 50, dan pada kelas kontrol adalah 43. Rataan nilai peserta didik pada kelas eksperimen 1 sebesar 84,9, kelas eksperimen 2 sebesar 76,07, dan kelas kontrol sebesar 67. Modus pada kelas eksperimen 1 adalah 93 dan pada kelas eksperimen 2 adalah 86 dan kelas kontrol adalah 57. Nilai tengah atau median pada kelas eksperimen 1 adalah 87,5 dan pada kelas eksperimen 2 adalah 79 dan kelas kontrol adalah 68. Rentang nilai pada kelas eksperimen 1 39, pada kelas eksperimen 2 adalah 46, sedangkan kelas kontrol adalah 50. Simpangan baku kelas eksperimen 1 sebesar 10,179, kelas eksperimen 2 sebesar 11,546, dan kelas kontrol sebesar 12,14.

Data amatan Uji N-Gain pemahaman konsep matematis dilakukan guna mengetahui berapa besarnya peningkatan pemahaman konsep peserta didik melihat dari data nilai pretest dan posttest yang diperoleh. Data hasil uji N-Gain pemahaman konsep matematis peserta didik dapat dilihat pada tabel berikut:

Tabel 6. Deskripsi Data N-Gain Kemampuan Pemahaman Konsep

\begin{tabular}{cccc}
\hline \multirow{2}{*}{ Nilai } & \multicolumn{3}{c}{ Kelas } \\
\cline { 2 - 4 } & $\begin{array}{c}\text { Eskperimen } \\
\mathbf{1}\end{array}$ & $\begin{array}{c}\text { Eskerimen } \\
\mathbf{2}\end{array}$ & Kontrol \\
\hline$X_{\max }$ & 1,000 & 0,907 & 0,837 \\
\hline$X_{\min }$ & 0,547 & 0,387 & 0,305 \\
\hline $\bar{x}$ & 0,780 & 0,643 & 0,510 \\
\hline$M_{o}$ & 0,746 & 0,671 & 0,426 \\
\hline$M_{e}$ & 0,801 & 0,671 & 0,510 \\
\hline $\mathrm{R}$ & 0,453 & 0,520 & 0,532 \\
\hline $\mathrm{S}$ & 0,120 & 0,124 & 0,114 \\
\hline
\end{tabular}

Terlihat pada Tabel 4.17 perolehan nilai $\mathrm{N}-$ Gain peserta didik dengan nilai tertinggi di kelas eksperimen 1 adalah 1,000, kelas eksperimen 2 adalah 0,907, dan kelas kontrol adalah 0,837. Nilai terendah peserta didik pada kelas eksperimen 1 adalah 0,547, kelas eksperimen 2 adalah 0,387, dan kelas Kontrol adalah 0,305. Rataan nilai peserta didik pada kelas eksperimen 1 sebesar 0,780, kelas eksperimen 2 sebesar 0,643, dan kelas kontrol sebesar 0,51. Modus pada kelas eksperimen 1 adalah 0,746, kelas eksperimen 2 adalah 0,671, dan kelas kontrol adalah 0,426. Nilai tengah atau median pada kelas eksperimen 1 sebesar 0,801, kelas eksperimen 2 sebesar 0,671, dan kelas control sebesar 0,51. Rentang nilai pada kelas eksperimen 1 sebesar 0,453, kelas eksperimen 2 sebsar 0,520, dan kelas kontrol sebesar 0,532. Simpangan baku kelas eksperimen 1 sebesar 0,120, kelas eksperimen 2 sebesar 0,124, dan kelas kontrol sebesar 0,114. 


\section{$\pi$ (Phi)}

Selanjutnya hasil pretest dan posttest yang diperoleh diujikan dengan uji ANOVA satu jalan yang kemudian dilakukan uji N-Gain untuk mengetahui berapa besar pengikatan yang terjadi pada kemampuan pemahaman konsep peserta didik.

Berdasarkan hasil penelitian serta uji hipotesis yang sudah diperoleh diatas, untuk mengetahui manakah model pembelajaran yang memberikan peningkatan paling berbeda terhadap pemamahan konsep matematis peserta didik, melalui uji komparasi ganda (schaffe) menggunakan SPSS. Hasil analisis dengan hipotesis pertama $\left(\mu_{1} \neq\right.$ $\mu_{2}$ ) perhitungan uji anova satu jalan didapatkan nilai sig. $<0,05$ sehingga $H_{0}$ ditolak, yang berarti terdapat perbedaan yang signifikan antara peserta didik dengan model pembelajaran probingpromting menggunakan bahan ajar desain didaktis dan model pembelajaran probingpromting terhadap pemahaman konsep matematis peserta didik.

Hasil analisis pada hipotesis kedua $\left(\mu_{1} \neq \mu_{3}\right) \quad$ didapatkan bahwa sig memperoleh nilai 0,000 sehingga nilai sig. $<0,05$, artinya $H_{0}$ ditolak, sehingga terdapat perbedaan yang signifikan antara siswa dengan model pembelajaran probing-promting menggunakan bahan ajar desain didaktis dengan model pembelajaran konvensional terhadap peningkatan kemampuan pemahaman konsep matematis.

Hasil analisis pada hipotesis ketiga $\left(\mu_{2} \neq \mu_{3}\right) \quad$ didapatkan bahwa sig memperoleh nilai 0,019 sehingga nilai sig. $<0,05$, artinya $H_{0}$ ditolak, sehingga terdapat perbedaan yang signifikan antara siswa dengan model pembelajaran probing-promting dengan model pembelajaran konvensional terhadap peningkatan kemampuan pemahaman konsep.
Jurnal Pendidikan Matematika Volume 5 Nomor 1 Tahun 2021

\section{KESIMPULAN}

Berdasarkan hasil penelitian dari analisis data dan pengujian hipotesis yang telah dilakukan, maka peneliti menyimpulkan bahwa terdapat pengaruh penggunaan model pembelajaran ProbingPromting menggunakan bahan ajar desain didaktis terhadap kemampuan pemahaman konsep matematis siswa. Pada kelas eksperimen terlihat suasan peserta didik lebih aktif dan antusias dalam pembelajaran sebab metode yang digunakan secara berkelompok dan heterogen. Oleh sebab itu, peserta didik yang memiliki kemampuan memahami konsep matematis yang rendah termotivasi dengan siswa yang memiliki kemampuan pemahaman konsep lebih tinggi.

\section{DAFTAR PUSTAKA}

A Susanto. (2018). Pemikiran Pendidikan Islam, Jakarta: Amzah

Achi Rinaldi, Novali, and Muhamad Syazali. (2020). Statistik Inferensial untuk Ilmu social dan Penididkan, Bogor: PT Penerbit IPB Press,

Alin Wahyu Rizkiah, Nasir Nasir, And Komarudin. (2018). "LKPD Discussion Activity Terintegrasi Keislaman Dengan Pendekatan Pictorial Riddle Pada Materi Pecahan”. Decimal: Jurnal Matematika 1, No. 1

Anna Fauziah. (2015). "Peningkatan Kemampuan Pemahaman Dan Pemecahan Masalah Matematik Siswa SMP Melalui Strategi React” Forum Kependidikan 30, No. 1 ,

Asrul Karin. (2012). "Penerapan Model Penemuan Terbimbing Dalam Pembelajaran Matematika Untuk Meningkatkan Pemahaman Konsep Dan Kemampuan Berpikir Kritis Siswa Sekolah Dasar”, Jurnal-Bull-Math.Org 1, No. 1 ,

Bambang Sri Anggoro. (2016). "Meningkatkan Kemampuan Generalisasi Mamtematis Melalui Discovery Learning Dan Model Pembelajaran Peer Led 
Guided Inquiry” Al-Jabar : Jurnal Pendidikan Matematika 7, No. 1

Ria Intansari. (2019). ”Desain Didaktis Materi Aritmatika Sosial Pada Madrasah Tsanawiyah" PEDIAMATIKA: Journal of Mathematical Science and Mathematics Education, 1, No. 2

Putra dan Anggraini. (2016). "Pengembangan Bahan Ajar Materi Trigonometri Berbantuan Software IMindMap pada Siswa SMA" Al-Jabar : Jurnal Pendidikan Matematika 7, No. 1,

Putri Wulandari, Mujib Mujib, and Fredi Ganda Putra. (2016). "pengaruh model pembelajaran Investigasi Kelomopok Berbantu Perangkat Lunak Maple Terhadap Kemampuan Pemecahan Masalah Matematis” Al-Jabar: Jurnal Pendidikan Matematika 7, No. 1

Rusman. (2012). Model-Model Pembelajaran, Jakarta : PT Raja Grafindo Persada

Simon, Martin A. (2017). "Explicating "Mathematical Concept" And "Mathematical Conception" As Theoretical Constructs For Mathematics Education Research"' Education Studies In Mathematics, 9, No. 2

Sudi Priyambodo. (2016). "Peningkatan Kemampuan Pemahaman Konsep Matematis Siswa Dengan Metode Pembelajaran Personalized System Of Instruction” Jurnal Musharafa 5, No. 1

Sulistiawati, Suryadi, and Fatimah. (2015). "Desain Didaktis Penalaran Matematis Untuk Mengatasi Kesulitan Belajar Siswa SMP Pada Luas Dan Volume Limas.” Kreano: Jurnal Matematika KreativInovatif 6, no. 2

Thahir, Mawarni, dan Palupi. (2019). "The Effectiveness of Demonstration Methods Assisting Multiplication Board Tools for Understanding Mathematical Concept in Bandar Lampung.” Jurnal Pendidikan Ilmuan Muda Berbakat 7, No. 2

Yanti, Fifit Novia, Farida, And Iip Sugiharta. (2019). "Analisis Kemampuan Pemecahan Masalah Matematis: Dampak Blended Learning Menggunakan Edmodo" Decimal: Jurnal Matematika 2, No. 2, 